\title{
Assessment of Food Security Situation in Afghanistan
}

\author{
Samim, S. $\mathrm{A}^{1,2,}$ and H. Zhiquan ${ }^{1, *}$ \\ ${ }^{1}$ Institute of Agricultural Economics and Development, Chinese Academy of Agricultural Sciences, Beijing \\ 100081, P.R. China \\ ${ }^{2}$ Faculty of Agriculture, Takhar University, Takhar 3702, Afghanistan.
}

\begin{abstract}
Food insecurity is a long-term critical problem in Afghanistan. In 2019, the food and agricultural organization (FAO) noted that more than $53.2 \%$ of Afghanistan citizens were food insecure, and a total of 11 million inhabitants need food aid. The main focus of this paper to understand food security variation, mainly where and under what natural and socio-economic situations Afghanistan citizens become susceptible to food insecurity. This article provides an overview of food security in Afghanistan with respect to the four principal components of food security, namely food availability, food access, food utilization, and food stability. It identifies the knowledge gaps in these four pillars of food security assessment and makes recommendations to advance the research policy linkage in the Afghanistan Agriculture sector. This study also highlights Afghanistan's current food production capabilities and the impact of social-economic factors on the four pillars of food security and suggests different procedures and policies improve it. In conclusion, this study provides a foundation for policy development to advance understanding and qualitative discourse to improve Afghanistan's food security situation.
\end{abstract}

Keywords: Afghanistan, Food security, Food availability, Food access, Food utilization.

\section{Introduction}

According to the FAO, "food security is achieved when all people, at all times, have physical and economic access to sufficient, safe and nutritious food to meet dietary needs and food preference for an active and healthy life" (FAO, 1996). This broad definition of food security accentuates four separate food security

*Corresponding author: huzhiquan@caas.cn Received: October 10, 2020

Accepted: December 4, 2020

Published: December 7, 2020 dimensions (Jones et al., 2013), which contains the food availability, accessibility, and utilization, in addition to the stability of each of those dimensions. That depends on the capability to survive shocks to the broader system of food. Food insecurity arises whenever any of the four pillars is not available, where understanding at the household level can be a transitory or a long time (Loopstra and Tarasuk, 2013). Food availability is reached when sufficient quantities of food are steadily 
available to all populations in the country; such kinds of food may be provided by households' local output, trade ports, or food aid (Bashir and Schilizzi, 2013). Access to food sufficiency is a central determinant of health; when achieved, family or households and all populations in a country must have had enough income to get suitable food for nourishing consumption (Loopstra and Tarasuk, 2013). Food utilization is its accurate biological expenditure and necessary consumption, which supplied adequate energy and vital nutrient (Vozoris and Tarasuk, 2003). Hence, the reduction, even temporarily in food consumption, can influence in long-duration the public health and damage human capital (Vozoris and Tarasuk, 2003). Therefore, based on the food and Agricultural Organization (FAO) report, a country increases food security when it guarantees sufficiency for the long term with a nourishing intake for the whole population (FAO, 2006). This food security concept shows a condition in a specific time and place where people live out of starvation. (FAO, 2006).

Food insecurity in the world affects more than 820 million people (FAO, 2019). The total food-insecure population is predicted to have increased in 2015 to 777 million people. Hence this situation has instigated the necessity for investigation and proposed measures to tackle malnutrition (Fortin et al., 2016). Afghanistan is considered to be one of the food insecure countries in the world, where a huge number of the population involved in undernourishment by disasters of environmental, four decades of conflicts of internal and external wars, poverty, limit household income, lack of employment, low wages, inadequate wheat production, and other grains crops, decreasing the production of livestock, inadequate water resources for agricultural, education deficiency and health services-mainly for women, indebtedness of widespread immigrant, and low level of education (USDA, 2012).

Therefore, a large portion of the Afghan population has been affected by chronic food insecurity and transitory food insecurity. This condition (chronic food insecurity) is becoming severe (World Bank, 2019) noted that $54.5 \%$ of the population lives below the poverty line in Afghanistan and above $53.2 \%$ of the total population is undernourished (USDA, 2019; FAO, 2019). Thus, this country was categorized as the 171 st food security country in the world in 2015, according to UNDP's Human Development Index (FSIN, 2017). This country has one of the lowest scores on the Human Development Index (0.496) (UNDP, 2019). Therefore, food insecurity is becoming permanent and a critical problem in Afghanistan. Almost 11 million people, or 35\% total population, needed emergency food and agricultural livelihood assistance, based on the U.N office for the coordination of Humanitarian Affairs 2020 Afghanistan Humanitarian needs overview (USDA, 2020).

Afghanistan is an Agricultural country, but Agricultural productivity is low due to high insufficiencies (practical, allocative, and economics). Some literature has identified challenges such as lack of resources, fluctuating markets, lack of crop storage facilities, inadequate agronomic methods, poor management practice, low-quality seeds, high input cost, poor management of water resources, lack of water supply, and climate variability, affecting production and resulting in low agricultural productivity(Gohar et al., 2013; Ahmadzai et al., 2017; Elham et al., 2020).

Numerous literature has also highlighted many problems, such as continued climate variability, 
high land fragmentation, poor credited availability, low adoption of advanced agricultural technology, low levels of education for farmers, lack of extension facilities, poor roads, and infrastructure, which are key obstacles to improving agricultural production in Afghanistan (Jilani et al., 2013), (Maletta et al., 2003, Tavva., et al., 2017, Thomas et al., 2011). Therefore, increasing agricultural production has profound significance for the increasing food security and poverty elimination in Afghanistan.

The most reason low productivity of agriculture in Afghanistan is war and conflict; the impact of war on the Agricultural sector's rapid and dramatic fall in cereal production followed the outbreak of hostilities in 1979. Afghanistan was almost self-sufficient in cereal in 1977, mainly due to the introduction of high-yielding seed varieties, large-scale irrigation systems, and increased mechanization (Clarke, 2000). But, during the four decades of war and conflict, irrigation infrastructures, institutions, and agricultural infrastructure were damaged; It can be one of the critical reasons for the low productivity of Agricultural. (Gohar et al., 2013) noted that undeveloped agricultural infrastructure is a critical problem to Agricultural productivity, food security, and livelihoods in Afghanistan. All so, several studies noted that lack of water supplies could be one important element of food insecurity, livelihoods, and farm income in this country (Gohar et al., 2013, Ward et al., 2013). Four decades of war and regular natural disasters continue to challenge Afghans' resilience in all aspects of their life. Thus, several studies found robust evidence that war and food security in the household are negatively correlated in Afghanistan (World Bank, 2019, Clarke, 2000; USDA, 2013).
Also, numerous studies pointed out that the price of food, the income of the household, drought is the major cause of food insecurity in Afghanistan and, there is a negative correlation between those factors and food security in Afghanistan(USDA, 2013),(WFP, 2020). The various regional, economic, cultural, environmental, and structural condition affects four dimensions of food security, but these have received inadequate attention in terms of both research and policy in Afghanistan. Food availability, food access, food utilization, and food stability differ due to natural conditions ( including climate change), levels of production, social-economic, physical infrastructure, food diversity, food processing, food storage, and stability of food (Ara et al.,) 2017; FAO, 2020). Hence, many studies have mainly focused on food availability to understand the impact of sources of food through food production, delivery, and exchange on food security (Mittal and Sethi, 2009; Trani et al., 2013, AKBAY and Ahmadzai, 2020, World Bank, 2019). However, these studies have a substantial limitation in considering social-economic factors impact on food security. Besides this factor, other factors such as bio-physical, management, poverty, food diversity, food process, low quality of food, and stability of food may affect all aspects of food security. Both the Afghanistan food security and Nutrition Agenda (AFSANA, 2012) and Afghanistan food security policy strategies plans (AFSNSP, 2018) do not address socialeconomic and food diversity effectively to decrease food security challenges in four aspects of food security. Four pillars of food security assessment are required to advance the research policy linkage in the country by considering such a system. In light of this gap, this paper assessed food security by considering 
four pillars of food security and provide an overview of Afghanistan's current food security situation.

\section{Methodology}

For achieving the objectives of this research, secondary data were collected from the World Bank database, FAOSTAT database, and published sources from 1989 through- 2018. This paper specifically examines the condition of food security based on four pillars of food security (i.e., food availability, food accessibility, food utilization, and food stability) in Afghanistan (Ara et al., 2017; Atara et al., 2019; Maxwell, 2001; Mohamed, 2017; FAO, 1996). This is an important way of measuring food security. The paper advances qualitative discourse and understanding of the dynamics of food security in Afghanistan, which can serve as an essential guide and information for policymakers and researchers who want to formulate and implement measures aimed to improve food security levels in Afghanistan.

\section{Discussions}

\section{Concept of Food Security}

The concept of Food security is a dynamic theory that, over the years, has policy and research steadily. The concept of Food security has a long history starting from the first half of the 1970s when the world's food crisis occurred (Clay, 2002).

Food security is such a complicated topic that it is impossible to measure directly it, and a number of integrated novel scopes and analytical stages. The new food security dimension has always been analyzed. This ongoing evolution of the food security concept represents a broader recognition of the complexities of definition in public of proxy methods that have been proposed. The most widely used food security measures are asset of four aspects of food security, nutritional status and coping strategies (Mohamed, 2017; Atara et al., 2019) and also Several studies noted that the most desirable measure of food security measurement on four major food security availability, access, utilization, and stability (Maxwell, 2013, Atara et al., 2019; FAO, 2000; FAO, 1996). Numerous definitions have been suggested to describe the concept of food security; approximately more than 200 definitions of food security and 450 indicators of food security (Mughal and Fontan Sers, 2020).

However, a definition that seems to be considered comprehensive is FAO's (FAO, 2000). Aware of the literature definition FAO generally conceptualized, Food security is terms used to define that people in the household have access to adequate food both in quantity and quality. Food security issues have gained prominence and greatly focused on international, national, household, and individual levels with advances in time and magnitude of the problem. Such innovative research has contributed to the redefinition of the breadth and depth of the idea of food security (Duffour, 2009). Hence, different institutions and organizations, in various ways, defined food security. Based on (FAO, 2008) food security is a condition that reached the international, national, household, and individual levels when "all people, at all times, have physical and economic access to sufficient, safe and nutritious food that meets their dietary needs and food preference for an active and healthy life." 
On the other side, some developed countries defined food security as financial ability. The Canadian government food security research center defined food security as "household food insecurity due to financial constraints has adequate or insecure access to food" (PROOF, 2017). The Agricultural Department of the United States defined food security as "To ensured access to adequate food, healthy living," which demonstrated that a household is classified as marginally, moderately, or severely food insecure according to their ability to buy food (Hamilton, 1997). Food security definition in recent studies as sufficient access to and availability of food for the family to meet the minimum energy needs as recommended for an active and healthy life (Hussein, 2013). Thus, a household is considered food insecure when the consumption decreases below $80 \%$ of the daily minimum recommended caloric allowance intake amount for daily activity and safe person. Food insecurity contains low food consumption and a lack of access to food. Also, poor resilience in front of shocks is an indicator of food insecurity (Mohamed, 2017). In total, food insecurity includes low-quality food, variability in access to food, and livelihood vulnerability strategy that creates adequate food in good times, but it is not robust against shocks.

\section{The food security situation in Afghanistan}

Afghanistan is located in the south of Asia. The total area of this country is $650000 \mathrm{~km}^{2}$ (NSIA, 2020). The population is estimated at around 37.1 million (NSIA, 2020). The average annual growth rate is $2.3 \%$ WorldBank in 2020 reported that $90 \%$ of Afghanistan's population is poor, and $75 \%$ live in rural areas (WorldBank, 2020). Afghanistan's climate is clearly defined as four seasons: hot summer and cold and dry winter (NEPA, 2016). The highest temperature is estimated at $54^{\circ} \mathrm{C}$ and the lowest $-54^{\circ} \mathrm{C}$ (Saidajan, 2012). Some provinces are impacted by climate from the Mediterranean, with short and erratic rainfall (UNEP, 2003). Afghanistan is an agrarian country; $80 \%$ of the population engaged in agriculture, husbandry, or both (NSIA, 2020). Only $12 \%$ of the land is suitable for irrigated and arable cultivation. $(46 \%)$ of the Afghan land is under permanent grasslands, and $39 \%$ of the homeland of this country is mountainous, and $3 \%$ is surrounded by forest (OXFAM, 2007).

Afghanistan's agricultural sector supports almost three-quarters of the overall population's livelihoods and contributes almost $28 \%$ to the gross domestic product (GDP) of Afghanistan (Muradi et al., 2018). Therefore, the growth of agriculture is vital for driving the economy of the country and maintaining food in national (World Bank, 2014). Agriculture provides an income for the household, food security, and jab for more than $80 \%$ of the population. In general, Livelihoods are heavily associated with the Agricultural sector in Afghanistan, but Agricultural is dependent on low performance, and it is not adequate to feed the population (FAO, 2017). The primary crops are rice, wheat, barley, maize, fruit vegetables, and nuts. Nearly $70 \%$ of the cropland is under wheat cultivation, and approximately $15 \%$ is under rice cultivation (NSIA, 2020), and the average size of the farmland is 1 to 2 ha (NSIA, 2018). Afghanistan is a developing country where more than half $(54,5 \%)$ or 16 million of the population live below the poverty line (World Bank, 2020). Poverty is steadily growing in Afghanistan.

Further, most of the economic indicators and growth indexes have not good progress in the 
last decades. Afghanistan has the least foodsecure country in the Asian region; the majority population is food insecure from consuming food and coping capacity. Food insecurity had an exact spatial dimension in Afghanistan base on the FAO estimation in 2016; over three quarters, $53.2 \%$ of the Afghanistan population were considered food insecure (USDA, 2019; FAO, 2019). In 2020 the FAO reported that $35 \%$ of the total population is acutely food insecure (FAO, 2020). Food security is very considerable across the country due to economic diversity opportunities and socialeconomic factors. Balkh, Ghazni, Paktya, Khost, Laghman, Badakhshan, and Logger provinces are high food insecurity in Afghanistan (World Bank, 2012). Based on the World Bank report in 2016, 60\% of the Badakhshan residence and $50 \%$ of the residence of the Badghis and Daykundi provinces are food insecure (World Bank, 2019a). Aside, based on the report of the World Bank in 2012 deficiency of calorie rate from less than $15 \%$ in Nangarhar, Parwan, Sar-i-pul, and Jawzjan to more and more rate $60 \%$ in Laghman and Badkshan province (World Bank, 2012). On the other side, based on the FAO report in $2020,75 \%$ of the total population of Afghanistan are living in rural areas, and among them, $90 \%$ are food insecurity (FAO, 2020). In this country, Food insecurity is increasing, namely the cause of coping capacity of economic, as the cause of pressure on the market of labor, employment loss, decreasing aid of humanitarian, with more effect of returnees refugees from the neighboring countries, ongoing conflict, economic shocks, declining security,(USDA, 2018). In either rural or urban society, the most significant food insecurity population characteristic is their human and physical resources, namely lack of access to education, limited land resources, and migrants of recent, high dependence ratio in the household. Geographically, the high rate of household food insecurity is in the mountain and deserts than the plains and hills since Agricultural production has been affected due to drought in these areas than the national average (FAO, 2017b).

In Afghanistan, Women and children are the most vulnerable part of people suffering from chronic malnutrition issues and are the highest in the World (FAO, 2020). Over $40.9 \%$ of Afghan children below the age of five are stunted (chronically malnourished), and more than 2.5 million children are acutely malnourished (FAO, 2020). The deficiency of vital micro-nutrients (such as iron and iodine) affects about $72 \%$ of children (below five years of age) (FAO, 2017). Such poor nutritional outcomes are associated with the country's state of food security. Hence, more than a quarter (29\%) of the population cannot meet their calorie requirements, i.e., the average per capita calorie consumption is lower than the world standard. In 2017, per capita calories a day was 2,090 kilocalories, and wheat is the chief source of calories for people in Afghanistan (Mughal, 2020). The main reason for malnutrition among people in Afghanistan is poverty, inadequate education, and childbearing in teenage years, gender inequality, insufficient child feeding and caring practices, lack access to important sanitation facilities, inadequate potable water, and hygiene (WorldBank, 2019a).

Hence, FAO noted that Afghanistan's food security situation is still surprisingly high, with more massive conflict, high unemployment rates, climate change, population growth, and other environmental issues (World Bank, 2019a). Besides, inflation and other vices, all mainly aggravated by the effects of the COVID- 
19 pandemic, will likely significantly impact the country's increasing level of food insecurity. $(35 \%)$ of the total population (10.9 million) estimated to be in an emergency (IPC) Integrated phase Classification Phase 3 and IPC Phase 4 in (April- May -2020). This comprises 3.5 million (11\%) listed in Phase 4 (critical situation) and 7.4 million (24\%) in Phase 3
(Crisis) (FAO, 2020). The number of malnourished people has increased steadily since 2001 (figure 1). But the Prevalence of malnutrition has decreased steadily since 2001 (Figure 1). In the period $2001-2018$, the number of Prevalence of undernourishment has reduced significantly from $47.8 \%$ to $29.9 \%$.

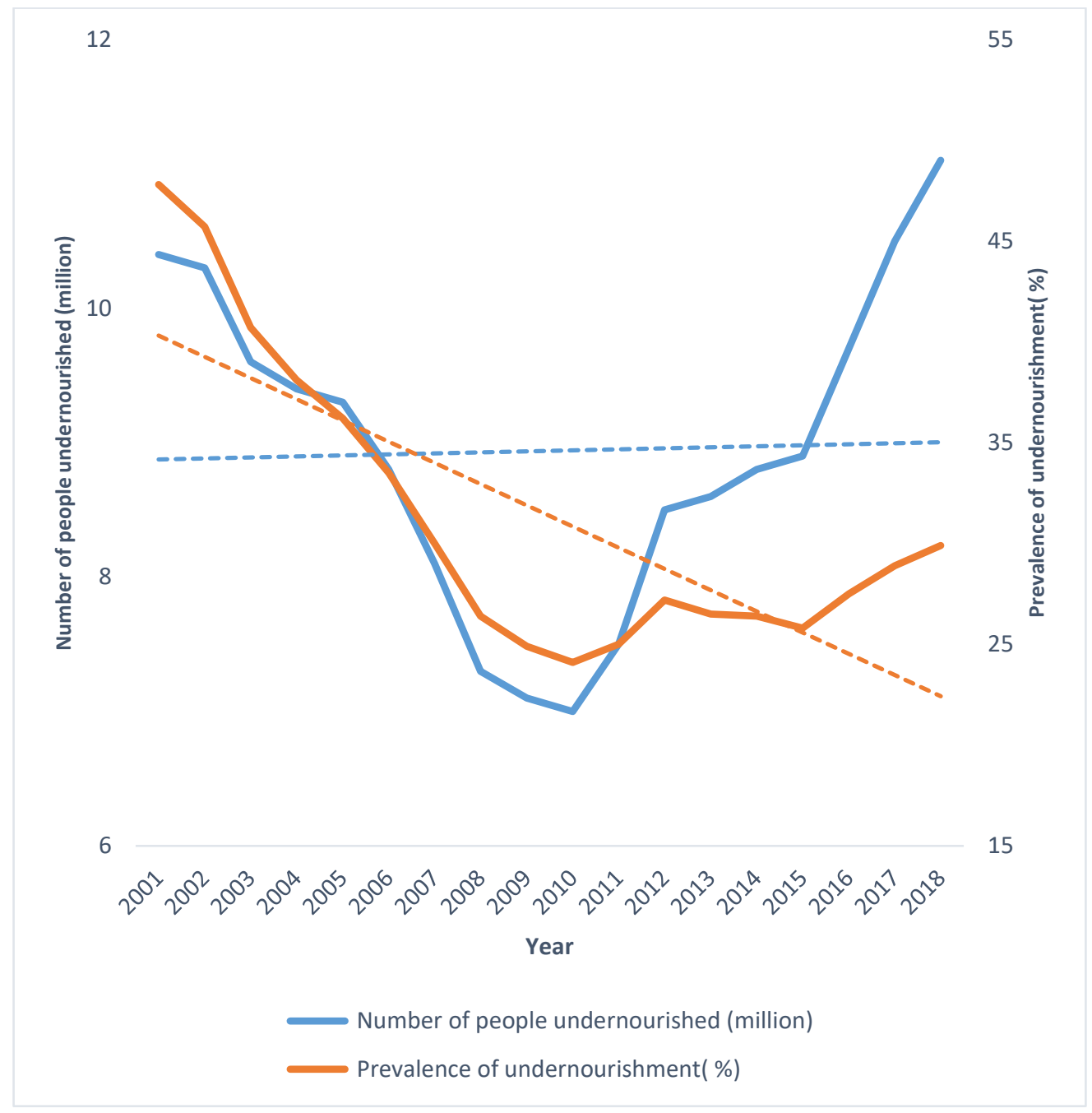

Sources: FAOSTAT (2019).

Figure 1: Prevalence undernourishment in Afghanistan in the period 2001/2018.

Notwithstanding, households in both urban and rural areas in Afghanistan are at risk of food shortage. Those households in the urban area suffered more economic crises, but rural households suffer natural disasters and insecurity (USDA, 2007). Hence, it assumed that Afghan families spent 56-77\% of their total income purchasing food (NRVA, 2008). World Bank Note that, vulnerability and hungry in Afghanistan were further aggravated by the 
COVID-19 pandemic (World Bank, 2020). Which has increased food prices; FAO has analyzed the market price, which shows an increase of $10-20 \%$ in the price of food in the market. The effects of COVID-19 on food security were assessed to be less severe in rural areas than urban (FAO, 2020). World Bank argued that the poverty rate might increase to between $61 \%$ and $72 \%$ over 2020 due to decreasing incomes and increasing prices for food and other vital household goods as a result of COVID-19 (World Bank, 2020). Generally, Food insecurity was affected by several factors, including unsuccessful government policies, security, insufficient infrastructure, lack of education and health services, particularly for women and children, inadequate human resources and skilled human resources, lack of employment opportunities, low level of agricultural technology, low agrarian production output (insufficient local cereals production particular wheat, decrease in the production of livestock), Insufficient water resources for agriculture, i.e., drought, increased natural disaster, wars and conflicts, Low wages and low household income, the distance of household from the market, inadequate health facilities, Widespread indebtedness, refugees and IDP migration, etc. All of these factors impede food security and threaten sustainable economic growth in Afghanistan.

\section{Kind of food security in Afghanistan}

\section{Chronic food insecurity}

Chronic food insecurity happens for a long time, and it might be considered to be almost a continuous situation. Chronic food insecurity affected households that cannot tirelessly buy sufficient food or produce food by their production system (FAO, 2005). Food insecurity and undernourishment are the most severe appearances of long term emergencies as they disrupt livelihoods in Afghanistan. This country has lived through foreign interference, civil war, insurgency, and widespread insecurity for four decades(World Bank, 2019b). Severely disrupted Afghanistan's economic growth trajectory, and the level of chronic food insecurity is higher. This situation slightly increased, the data from FAO between (2014- 2017) indicate the percentage Prevalence of moderate food insecurity, in (2014- 2015) the Prevalence of moderate food insecurity was $(45,1 \%)$, but this situation during (2016 -2017) slightly increased to over $60.8 \%$ figure (2).

Additionally, Afghanistan's residence consumption is not only an insufficient quantity but also qualitative inadequacy. In this country, over half of the residents have borderline food consumption, which is high among the rural population. Based on the word bank estimation, more than $30 \%$ of Afghan people have not consumed sufficient protein (per day per person $50 \mathrm{gr}$ ) in their foods. Hence insufficient quantity and quality of food are more and more severe on the nearly 1.4 million children under the age of five (WorldBank, 2019). 


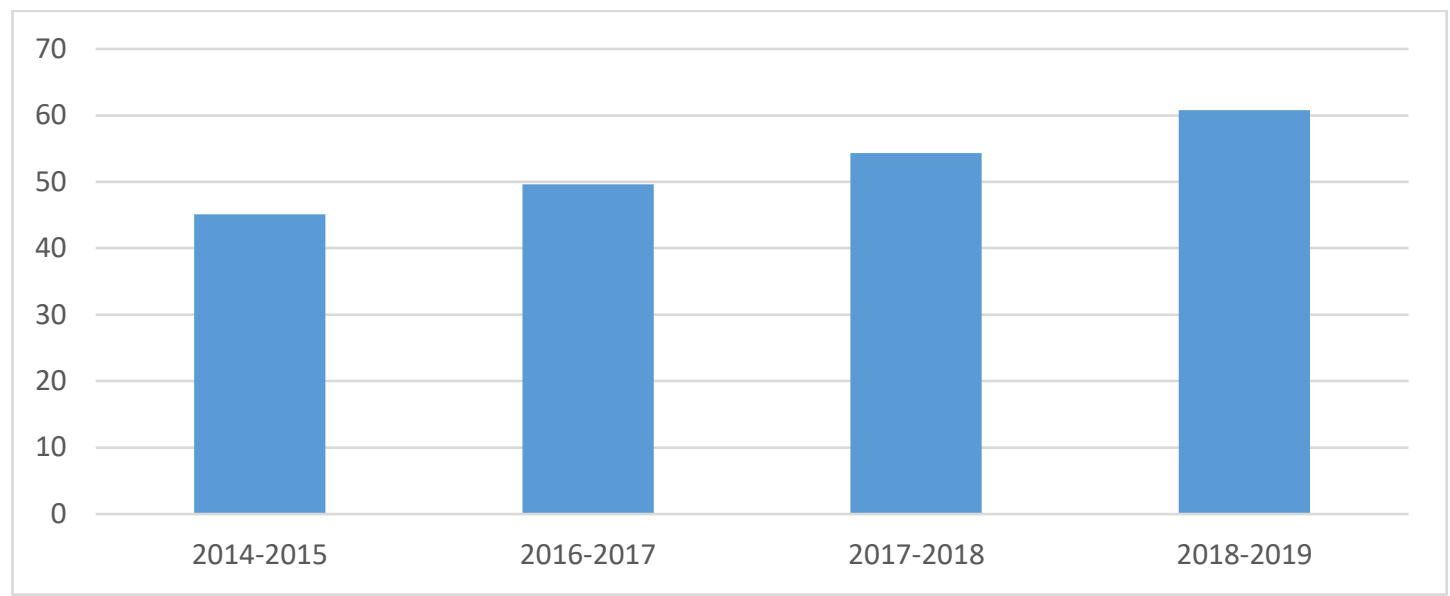

Sources: FAOSTAT (2019).

Figure 2: Percentage of moderate food insecurity in Afghanistan in the period 2014/2019.

\section{Transitory food insecurity:}

This kind of food insecurity usually happens on a short-term and transitory basis and denotes short food availability and access phases. This situation includes shocks belong to climatic, natural catastrophes, economic shocks, and Conflict (FAO, 2005). Transitory food insecurity may affect, through smaller shock, at the small level in the household, for instant income loss, failure of the crop to impact the food access and availability. Still, this state, when the condition was not normal, can be severe and unpredictable (FAO, 2005). (USDA, 2007) noted that in Afghanistan any year, nearly 400,000 people are severely affected by weather disasters, such as drought, floods, earthquakes, and weather problems. It means that some of these catastrophe victims, in one way or the other, suffer from short-term or transitory food insecurity.

\section{Seasonal or cyclical food insecurity:}

This kind of food insecurity happens when there is a cyclic pattern of insufficient access to food. This is a problem linked to climate change, cropping patterns, work opportunities, and the occurrence of diseases (FAO, 2017a). For instance, when the national supplies of food and household are inadequate, and the prices of food are higher than the time of post-harvest, it is usually measured more forecasted simply the situation of food insecurity will happen as it is known (Hart, 2009). Seasonal food insecurity happens among chronic food insecurity and transit food insecurity. Generally, since it is a known and frequent phenomenon, it is assumed to be more easily predicted than temporary food insecurity. However, seasonal food insecurity has a limited duration. Seasonal malnutrition is common food insecurity in Afghanistan. The cause of seasonal food insecurity in 2016-17 was more severe during the winter months. Compared to a yearly average of $37 \%$ of the population experiencing adequate food security, this drops to $17 \%$ (World Bank, 2019a). (Figure: 3 ).

Afghanistan's food security has a clear seasonal character (World Bank, 2012). In Afghanistan, seasonality plays an important role in food security. With hot summers and cold winters, temperatures differ significantly across the season, and the climate in the highlands varies with elevation. In certain cases, extreme winter situations impact travel, and roads are frequently blocked throughout the 
cold season in high mountain areas due to the heavy snow accumulation (FAO, 2017). In specific in these places, households are compelled to rely solely on food supplies stored before winter. Therefore a wide variance in the security of food outcome across the various season will be expected (World Bank, 2012).

Table 1: Type of Food insecurity in Afghanistan by season (\%).

\begin{tabular}{|l|l|l|l|l|l|}
\hline Season & Spring & Summer & Autumn & Winter & Total \\
\hline Adequate food security & 44 & 51 & 41 & 20 & 39 \\
\hline Moderate food insecurity & 17 & 17 & 17 & 12 & 16 \\
\hline Very severe food insecurity & 16 & 16 & 18 & 19 & 17 \\
\hline Borderline food secure & 13 & 10 & 13 & 21 & 14 \\
\hline Severely Food Insecure & 10 & 10 & 11 & 27 & 14 \\
\hline
\end{tabular}

Sources and notes: W.B. estimates based on ALCS 2016-2017.

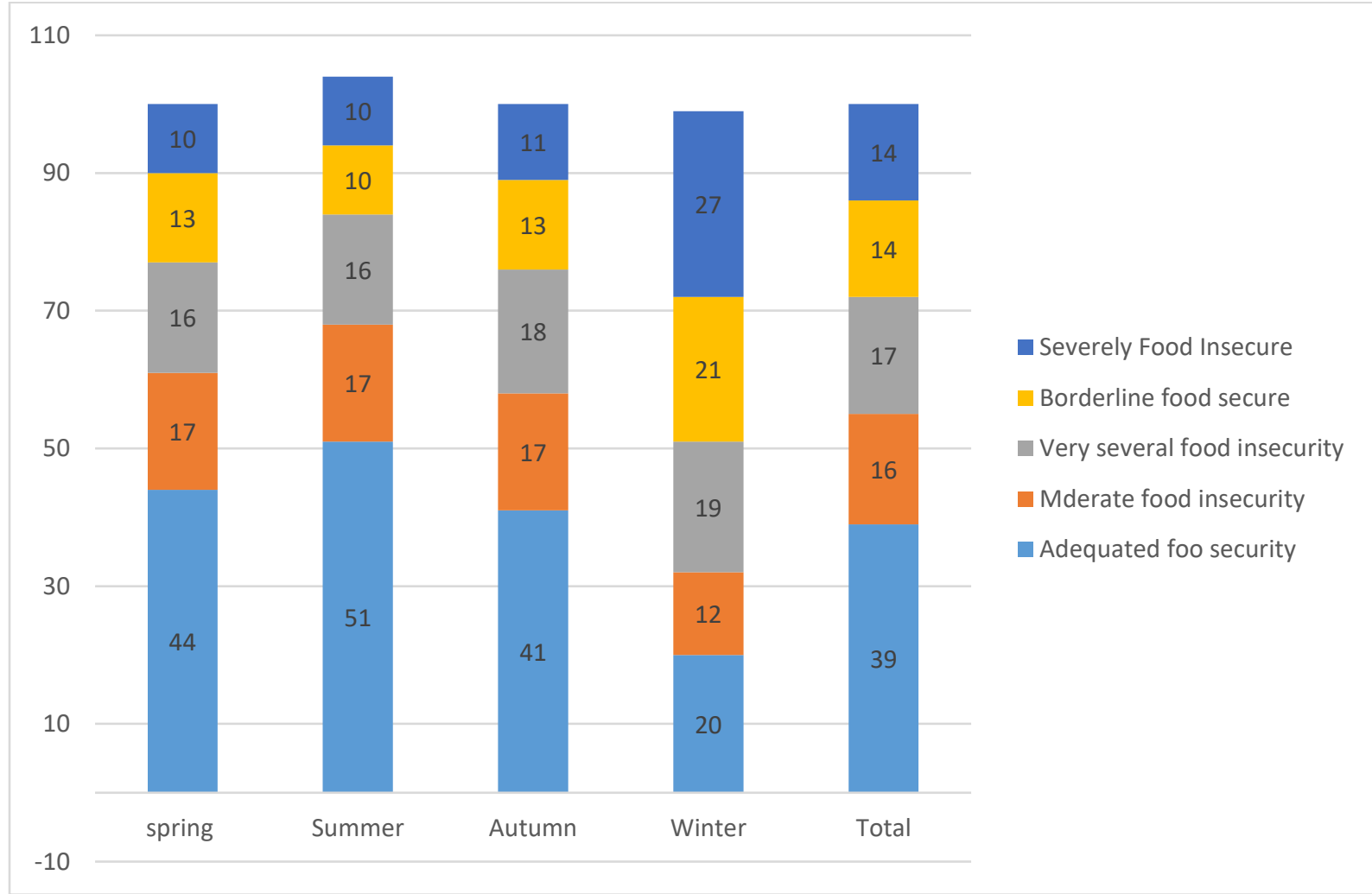

Sources and notes: W.B. estimates based on ALCS 2016-17

Figure 3: Kind of food insecurity by season in Afghanistan in the period 2016/2017.

Pillars of food security in Afghanistan:
WHO noted that three dimensions determine food security: availability of food, accessibility 
of food, and food utilization? The FAO added food stability as the fourth dimension of food security in 2009. The World Summit on Food Security specified that "four dimensions of food security are food availability, food utilization, food access, and food stability (Oyakhilomen, 2015). On the other hand, the conceptual framework of household food security adopted by contemplates dimensions of food security (food availability, food access, food utilization, and food suitability) as a central determinant that is indicated as primary tools for determining food security (WFP, 2009). Hence, food insecurity is the main issue in Afghanistan, and the people of Afghanistan have many challenges in the sufficiency of four dimensions of food insecurity.

\section{Food Availability:}

Food availability refers to the adequate food provided through local production, stores, imports, and food aid (WFP, 2009). Food availability depends on food at the global, national, household, and individual levels (Anderson, 2015). In general, the availability of food-dependent food sources through production, delivery, and exchange is determined by different factors, including ownership of land and use; soil management; crop selection, breeding, management; livestock breeding and management; and harvesting(Mohamed, 2017). Changes in rainfall and temperatures can impact crop production. Land, water, and energy to produce food frequently compete with other usages, which can affect food production, unsustainable agricultural practices. Land used for agriculture can be used for urbanization or lost to desertification, salinization, and soil erosion due to unsustainable agricultural practices; therefore, Crop production could not achieve food security. (Parvathamma, 2015).
In Afghanistan, food availability is dependent on cereal crops (Wheat, rice, and maize) production; among cereal crops, wheat is the main food staple crop. Based on (NRVA) Report, 89\% of people living in Afghanistan prefer to eat wheat (Mittal and Sethi, 2011). Wheat flour consumption in Afghanistan is very high, contributing to about $57 \%$ of total caloric content (AFSANA, 2012). Additionally, the per capita consumption of wheat in Afghanistan is $170 \mathrm{~kg} / \mathrm{yr}$, and this rate is higher in Asia, where the average consumption of wheat per capita is $66 \mathrm{Kg} / \mathrm{yr}$ (Chabot and Dorosh, 2007). Thus, the average production of wheat is low in both irrigated (2, $65 \mathrm{t}$ hectares) and rain-fed systems (0,298 thectares) (Chabot, 2007). Hence, in Afghanistan, wheat production variability is highest based on the USDA report; the coefficient of variation for wheat production was 0.27 between 2001/2002 and $2010 / 2012$ (USDA, 2012). Hence, around $70 \%$ of Afghanistan's cultivated area is under wheat cultivation over the period of 1989 2004. About $52 \%$ of the places for wheat cultivation were irrigated area, amounting to $91 \%$ of the total wheat production $(3,07 \mathrm{mt})$, and Rainfed wheat area $48 \%$ contributes only $9 \%(0,3 \mathrm{MT})$ of total wheat production (Chabot, 2007). Wheat production from irrigated land is three-times significantly larger than the rain-fed land (1, 8 tone/ha versus 0,6 tone/ ha). Other cereals crops such as barley and maize are produced mostly for animal feed, and the cultivated area is $15 \%$ (Chabot and Dorosh, 2007).

Afghanistan still has a significant deficiency in overall food grain production, including wheat, leading to food insecurity. Based on the Statistical Year Book of Afghanistan (20112012), on average, Afghanistan imports 30$35 \%$ of wheat domestic for consumption food 
demand (NSIA, 2020). Thus, wheat is the primary source of calories and the main suitable crops in Afghanistan; we estimated the wheat availability from the annual production and annual consumption in the duration of (1989/2018). The data indicate that wheat production in Afghanistan is below the consumption level; it is apparent in figure (4).
The data interpreting the national production of wheat sharply increased from 1725 thousand tons in 1998 to 4327 thousand tons in 2018. Still, the consumption increased from 1735 thousand tons in 1998 to 7600 thousand tons in 2018. However, there is a clear result that this country has a crucial problem in the case of food availability.

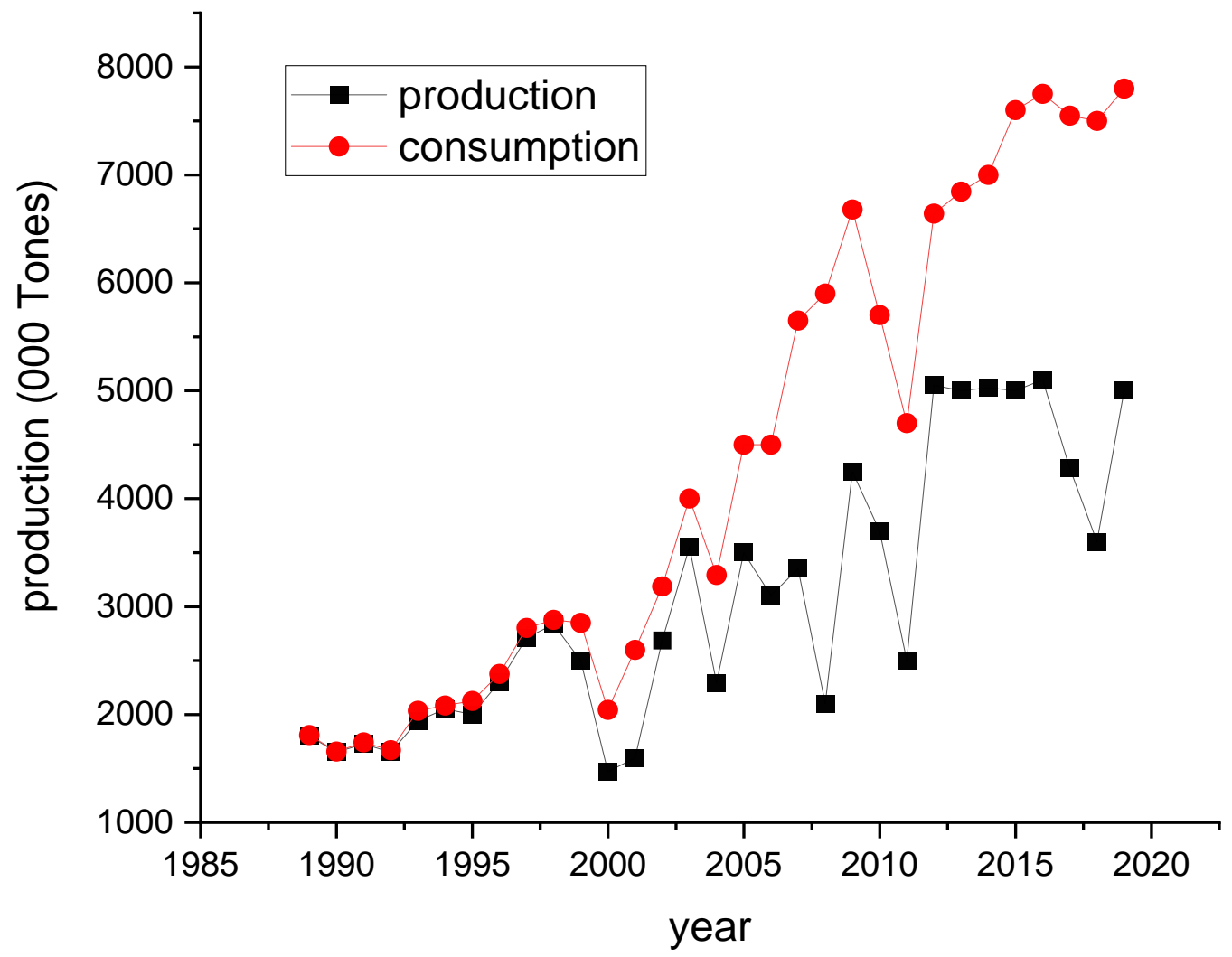

Sources: FAOSTAT (2019).

Figure 4: Total wheat production and consumption of 1000 tons in the period of 1998/2018.

\section{Food Access:}

Access to food consists of three components, which are physical, financial/economic, and social culture (Ara and Ostendorf, 2017). The physical dimension is when food is produced in one part of the country but inadequate in the other. The transportation system to another part is poor; therefore, this part is suffering from food insufficiency. Economic components happened when food insecurity was arising, and food is available, but the people are unable to buy because of inadequate economic resources. Further economic attention is the significance of market systems to ensure food access 
(OXFAM, 2007). The third factor affecting food access is social-culture. This component occurs when food is physically available, the people have money to purchase, but this is prohibited from being a member of a particular social group or even being a gender social conflict. Civil strife can seriously disrupt food production and lead to the loss of livestock. For example, with dire consequences for a household's future food security, conflict, war can seriously prohibit food production and lead to the lack of productivity of husbandry and agriculture (Riely, 1999). Hence, food access at the household level refers to the household resource either own production or purchase; therefore, the household needs to have assets or income to produce or purchase food for their consumption (Kuwornu, 2011). Additionally, the available income of the household, distribution of income, food price in the market, social and institutional rights of the household has many impacts on food access at the household level (USDA, 2015).

Food access in Afghanistan is mostly dependent on the physical and economic constraints, which are often worsened by conflict, natural disasters, and climate-related concerns. In Afghanistan, most people (73\% in rural households and $97 \%$ in urban) depend on the market for buying essential foods (NEPA, 2016). But the access to the market is poor for the population of Afghanistan. In 2019 World Bank reported that $12 \%$ of the population lives in areas with low availability to markets (measured by the household live more than 12 hours) (by foot or bicycle) away from the nearest market. Aside, in some places in this country market is not accessible (World Bank, 2019b). Therefore, this condition has an increasing impact on food access, aside from dependence on regional markets and trade with neighboring countries leading to higher food prices. The stability of the country's food supply depends on its economic status and agricultural productivity. Afghanistan experiences a cereal deficit even in years with good harvests. It mostly relies on imports; though food imports cover the production-demand gap, the country still experiences a "nutrition gap" (UNICEF, 2012). Agricultural productivity and economic well-being are heavily influenced by conflict and climate; the country's complicated political situation and long history of unrest present challenge to achieving economic success, which also has trickle-down effects on a relatively underserved agricultural system (Mittal, 2011). The second factor that affected food access in Afghanistan is related to a lack of income (AFSANA, 2012). This country is located among the low-income country in the world (World Bank, 2019). Therefore, income per capita per person is lower, and it has many negative problems in access to food (World Bank, 2020).

On the other side, over half of the population, approximately 16 million people in 2016-17, living below the poverty line, and poverty increased over the last decade (WorldBank, $2019 b)$. This country is one of the ten countries in the World in terms of unemployment vulnerability, but this situation is steadily decreased since 1993 figure (5). It indicates progress, which can be important in the reduction of food security. Based on the World Bank data, between 16 million food-insecure populations, 9.7 million are poor. Approximately $20 \%$ of the poor residents consumed not more than 11 food items on average, half the number of items consumed by the wealthiest 20\% (World Bank, 2019b). There is evidence of low nutritional variety between Afghan households. Over-reliance on staple 
grains as a source of cheap calories and threequarters of calories of Afghans poor residence comes from grains alone, mainly from wheat. Non-poor Afghans also eat two-thirds of their calories from grains crops, but their food consumption is a little more diversified with higher shares of dairy products (Chabot and Dorosh, 2007).

Increasing the price of staple food affects the house's access to food in Afghanistan. Several studies noted that the increase in the price of food and food access has a negative correlative due to the lack of income, lack of access to land, lack of access to water supplies, vulnerability employment (Gohar et al., 2013; World Bank, 2012; AFSANA, 2012). Based on the World Bank report, the impact of price shock has a severe effect on the rural of Afghanistan than the city in terms of access to food (World Bank, 2012). In particular, access to infrastructure services, overall food distribution distance within a country, location growth centers, and electricity access, low constriction, lack of transport, war, conflict, lack of market, insecurity conditions (WFP, 2009), (AFSANA, 2012), may affect food access in Afghanistan.

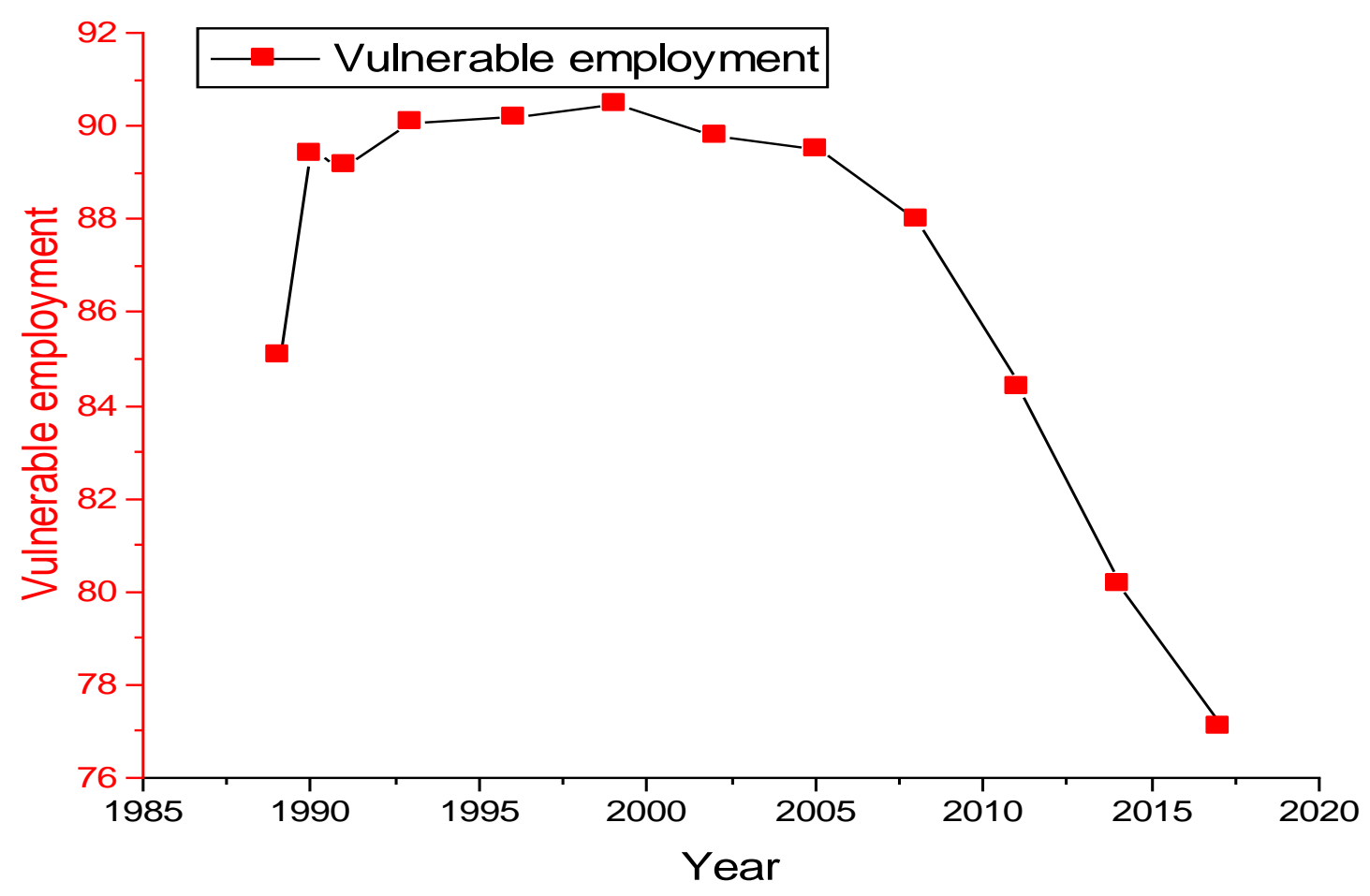

Sources: FAOSTAT (2019).

Figure 5: Vulnerability employment in Afghanistan in the period of 1993/2019.

\section{Food Utilization}

Food utilization dimension depends on families' consumption and persons' capability to metabolize and absorb the nutrient (WFP,
2009). Additionally, FAO noted that utilization of food involves the beneficial well-being of a people that has adequate food utilization from food diversity, storage of food, and processing, 
including clean water and healthy environments (FAO, 2016). Therefore, Agriculture is an approach for improving nutrition; there are numerous linkages between agriculture and nourishment, such as the provision of food, employment, income, and a healthy environment (Hawkes et al., 2011).

Food utilization has always been unsatisfactory nationally in Afghanistan. Undernourishment in Afghanistan is one of the most severe problems of health and development. The Afghan population's food consumption is not only insufficient in quantity; it also has low quality; based on the World Bank report in 2019, overall, half of the total population of Afghanistan also has borderline food intake (World Bank, 2019b). This condition is highest in the rural area amounting to $30 \%$ of Afghans who do not eat adequate protein (50gr per person per day) from their food (WorldBank, 2019b). Hence, National Survey (NNS) noted the high rates of malnutrition between vulnerable groups; for example, children below the age of five, $40 \%$ particularly have severe effects. Nearly 1.4 million children under the age of five are vulnerable to malnutrition (UNICEF, 2014).

Additionally, the lack of diversity in the diet is one of the vital dimensions of nourishment insecurity. In Afghanistan, food nourishment solely depends on wheat feeding (Poole et al., 2018). Generally, Afghani people usually have a staple diet from wheat bread and tea. Approximately $70 \%$ of rural households have low dietary diversity (Poole, Amiri et al., 2019). This national-level per person per day of food consumption was obtained in FAOSTAT from
1989 to 2018 for different grams of food items. The Data were converted into kcal in two sections of wheat and other major food items including rice, barley, maize, millet, potato, sugar, Notes, Pulses, Sesame seed, Soybean, Sunflower seed, Palm Oil, Vegetables, Grapes, Bovine Meat, Milk, Fat by using their nutrition values. Wheat consumption steadily increases from 1989 (1055 kcal) to $(1331 \mathrm{kcal}) 2018$ figure (6). Our result demonstrates that the calories consumed from wheat in Afghanistan $50 \%$ bigger than all types of food. Hence, wheat's calorie consumption is high in Afghanistan than in other Asian countries (Chabot and Dorosh, 2007).

The reason for malnutrition in this country includes poverty, low education, during adolescence of childbearing, gender inequality, insufficient child and feeding, lack of access to the primary health services, low-quality water, and food insecurity (WorldBank, 2019b).

Many aspects of food security and inequality of gender also donate to Afghanistan's undernourishment by their thru impacts on food insecurity. Food quality control systems for locally processed and imported foods are weak due to the absence of recognized standards, legislation, regular inspection systems, and border controls of food security. Gender inequity is manifested in inadequate access to services, control over resources, and, unfortunately, economic opportunities in the health, education, and agricultural sectors; the adverse effects of such inequities on malnutrition are evidenced via inter- and intrahousehold food distribution (AFSANA, 2012). 


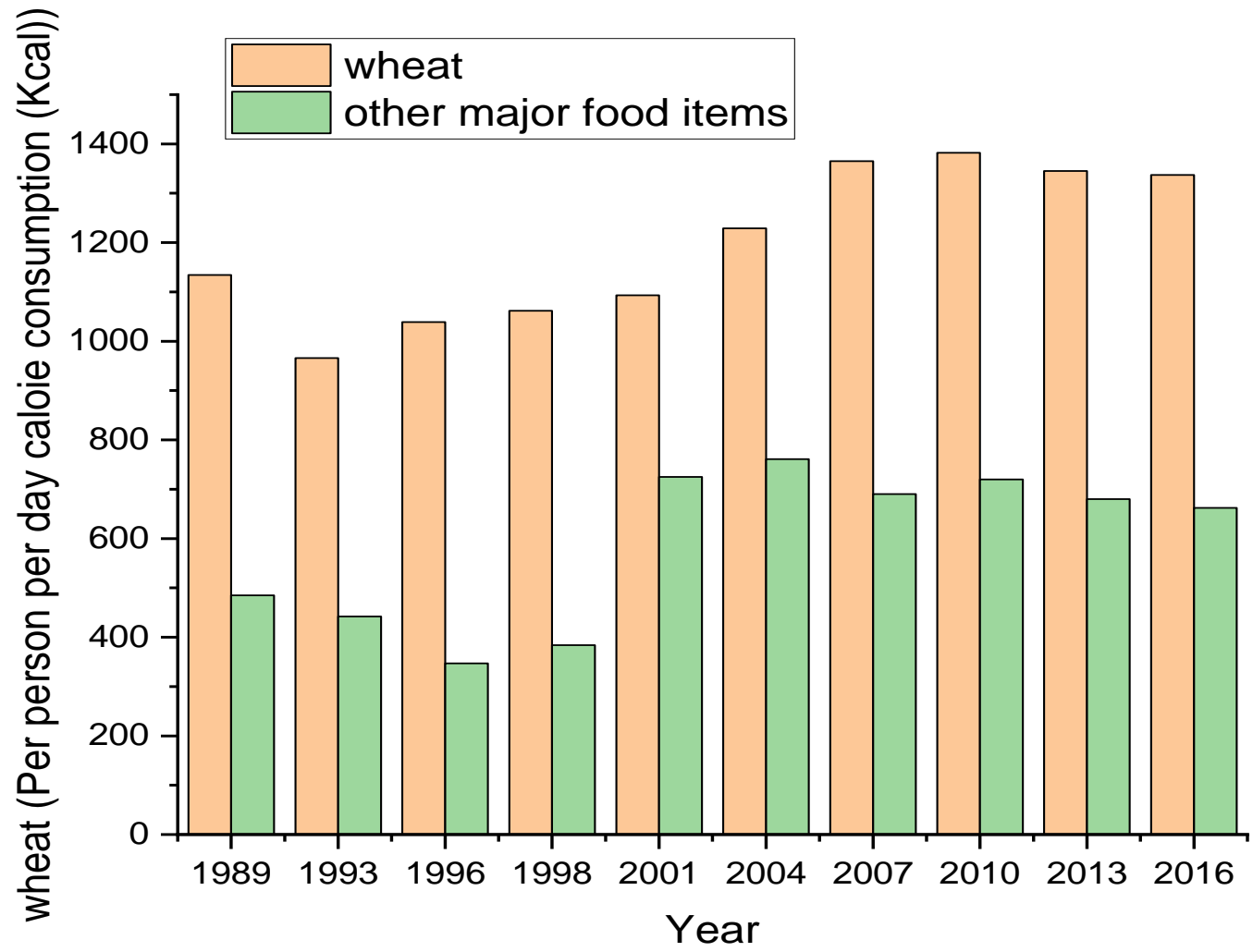

Sources: FAOSTAT (2019)

Figure 6: Average per person per day calorie consumption (kcal) from wheat and other major food items in Afghanistan during 1998/2017.

\section{Food stability}

The dimension of Food stability refers to the strength of the three dimensions of food security over time, indicated in figure (7). Even if your food consumption is sufficient now, you are still considered to be food insecure if you have insufficient access to food based on periodic risks, a worsening of their nourishing condition. Effect of the state of the weather, instability of political or economic shocks (increasing prices of food, joblessness) have an impact on the status of food security (FAO, 2008). Therefore, in Afghanistan, food stability was affecting by many factors in the country, such as ongoing conflict that involved all dimensions of food security; also seasonal factors that affected household food stability (FAO, 2019). This includes increasing food prices, depletion of inadequate household feedstock, and the limited chance of wage labor caused by the reduction in agriculture activities. Food stability can be temporary, cyclical, or chronic. In the situation of temporary food insecurity, it may not be available at certain times. Crop failure has affected food production leading to, food availability decreased, and conflicts also can reduce food access; market instability can be resulting in food-price spikes that can cause transitory food insecurity (WorldBank, 2019b). 


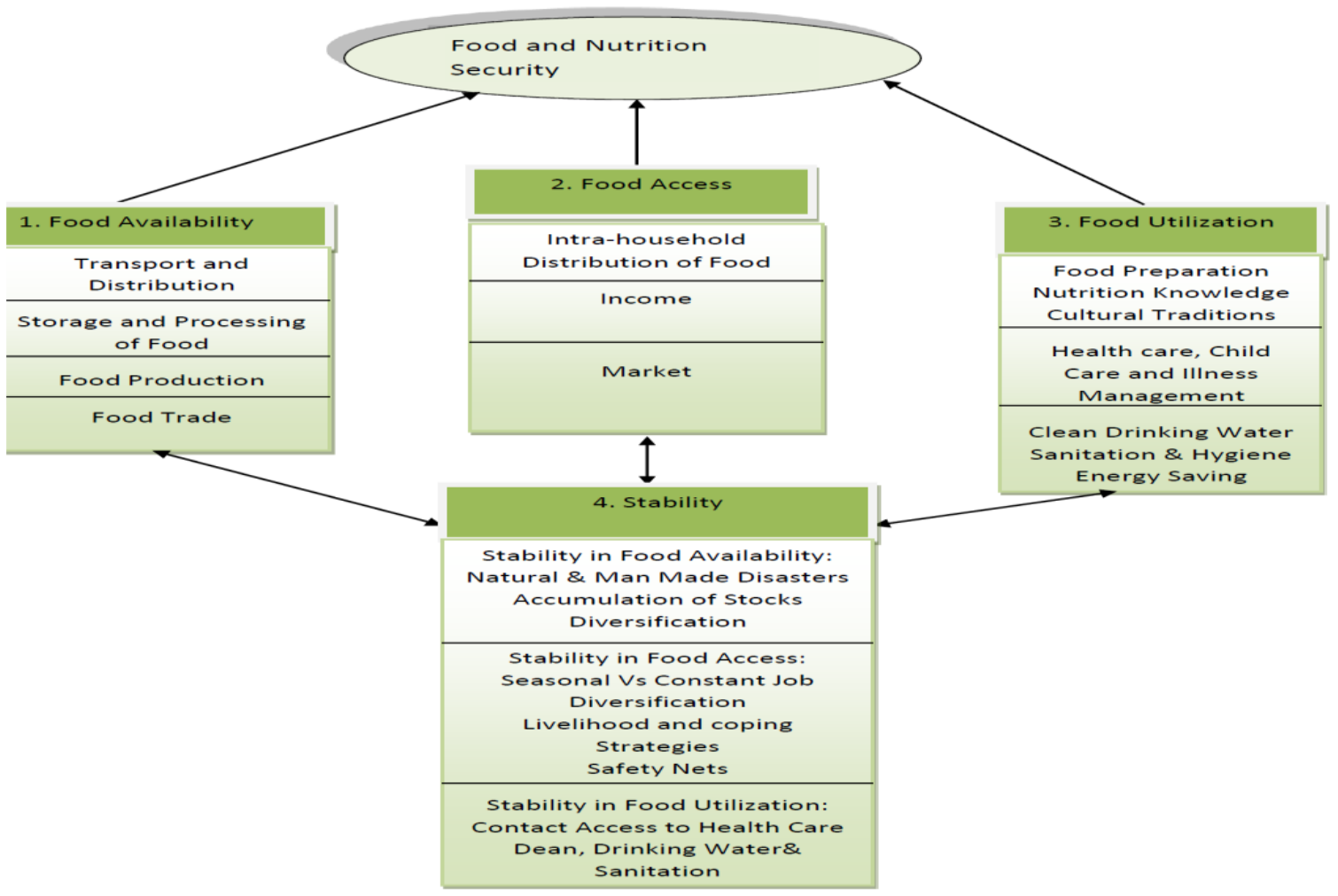

Figure 7: food and Nutrition security Dimension.

\section{Conclusion}

The present study has shown that food security is a permanent, critical problem in Afghanistan over the years. Afghanistan is considered to be one of the food insecure countries in the world. Poverty and war are the main issues of food insecurity faced by the Afghan population. More than half, $54.5 \%$ of Afghanis' people live below the poverty line, and $53.2 \%$ of this country's total population is food insecure, and $35 \%$ more thane11 million people are acute food insecurity.

The study identified the effect of three kinds of food security (chronic, transit, and seasonal) in Afghanistan. The result indicates that chronic food insecurity has rapidly increased since 2014 due to the increasing war, conflict, an immigrant from neighboring countries, and decreased income. Our result indicates that, in the winter season, the level of food insecurity higher than the other seasons due to cold weather and unemployment; in the year 2016, severe food insecurity increased in autumn to winter from $11 \%$ to $27 \%$.

The present study has improved the Assessment of food security in considering four pillars of food security- availability, access, utilization, and stability. Our result indicates that Afghanistan still has a significant deficiency in overall food grain production due to the low productivity and numerous social-economic factors, including lack of access to market, lowincome, war, conflict, the high price of food, poverty has a direct effect on food access. Food access is severe in a rural area than in the city. in this study also, our result found that the 
Afghan population's food consumption is not only insufficient in quantity; it also has so low quality, it can be a main problem in the future, and food variety is so poor, our result found that calorie consumption from wheat two times bigger than all type of food per day in Afghanistan. Overall, Many factors affect food stability in Afghanistan, such as ongoing conflict, seasonal factors, insufficient food, and low income.

The findings have several implications for policy: firstly, given a large level in food insecurity outcomes at the across the country, better targeting is crucial to increase the effectiveness of food security.

Secondly, the evidence highlights that if policymakers focus on the aspect of Food accessibility and food utilization, would help secure better food security.

\section{References}

AFSANA. (2012) 'Afghanistan Food Security and Nutrition Agenda (AFSAND) policy and strategic framework', Kabul -Afghanistan, Government of the Islamic Republic of Afganistan.

AFSNSP. (2018) 'Afghanistan Food Security and Nutrition strategec Plan', Kubul, Afghanistan.

Ahmadzai, H. (2017). Crop diversification and technical efficiency in Afghanistan: Stochastic frontier analysis. PhD. the University of Nottingham, Center for Research in Economic Development and International Trade, Amrica.

Anderson. (2015) 'Food Security Country Framework for Ethiopia', Rome, USAID.
Ara, I., and Ostendorf, B. (2017) 'food security and the potentials to develop spatially informed food policies in Bangladesh a review', Earth Systems and Environment, 1(2), pp. 19.

Atara, A., Tolossa, D., and Denu, B. J. G. (2019). Assessment of food security situation of the rural households: the case of Boricha Woreda of Sidama Zone, Ethiopia, pp. 1-17.

Bashir, M. K., and Schilizzi, S.. (2013) 'Determinants of rural household food security: a comparative analysis of African and Asian studies', Journal of the Science of Food and Agriculture, 93(6), pp. 1251-1258.

Chabot, P., and Dorosh, P., (2007) 'Wheat markets, food aid and food security in Afghanistan', Food Policy, 32(3), pp. 334-353.

Clarke, P. J. D. (2000) 'Food Security and War in Afghanistan', 43(3), pp. 113-119.

Clay, E. (2002) 'Food security Concepts and measurement', paper for FAO Expert Consultation on Trade and Food security Conceptualizing the Linkages, Rome: Food and Agriculture Orrganization of the United Nations

Devereux, S., Baulch, B., Hussein, K., Shoham, J., Sida, H. and Wilcock, D. (2004) 'Improving the analysis of food insecurity - Food insecurity measurement', livelihoods approaches and policy: Applications in FIVIMS, 2(3),pp. 1-55.

Duffour, K. (2009) 'The Budget statement and economic policy of the government of Ghana for the 2011 financial year', Presented to Parliament on Wednesday, 18th November 20011,pp. 1-52 
Elham, H., Zhou, J., Diallo, M. F., Ahmad, S., and Zhou, D. J. J. o. A. S. (2020). Economic Analysis of Smallholder Maize Producers: Empirical Evidence From Helmand, Afghanistan 12 (3).

FAO. (1996) 'Declaration on World Food Security and World Food Summit Plan of Action', Food and Agriculture Orrganization of the United Nations, Rome,Italy.

FAO. (2000) 'The state of food insecurity in the world. Food and Agriculture Organization of the United Nations , Rome, Italy.

FAO. (2005) Assessment of the world food security situationCommittee on World Food security,Food and Agriculture Organization of the United Nations, Rome: Italy.

FAO. (2006) 'The state of food insecurity in the world, eradicating world hungertaking stock ten years after the world food summit.Food and Agriculture Organization ,Room Italy .

FAO. (2008) 'Climate change and food security- a framework document, Food and Agriculture Organization, Rome, Italy.

FAO. (2017) 'Seasonal Food Security Assessment in Afghanistan (SFSA), food and Agriculture Organization, Rome. Government Media and information center.

FAO. (2017) 'the State of Food Security and Nutrition in the World, food and Agriculture Organization. Room, Italy.

FAO. (2019) 'The state of food insecurity in the world, Safeguarding against economic slowdowns and downturns. Rome Food and Agriculture Organization of the United Nations.
FAO. (2020) 'Integrated food security phase clasifacation in Afghanistan. Rome, Food and Agriculture Organization of the United Nation.

Fortin, S., Kameli, Y., Ouattara, A., Castan, F., Perenze, Maria L, Kankouan, J.,Martinrével,Y., (2016) 'Targeting vulnerable households in urban Burkina Faso: effectiveness of geographical criteria but not of proxy-means testing', Health policy and planning, 31(5), PP. 573581.

FSIN. (2017) 'Global Report on Food Crises, Food and Agriculture Organization of the United Nation, WFP and Unicef. Pp. 13: 97-10.

Gohar, A. A., Ward, F. A., and Amer, S. A. J. J. o. H. (2013). Economic performance of water storage capacity expansion for food security. 484, 16-25.

Hamilton, W., Cook, JT., Thompson, B., Frongillo, EA., Olson, D., and Wehler, C., (1997) 'Household Food Security in the United States in 1995: Summary Report of the Food Security Measurement Project. Washington, DC: US Department of Agriculture. Food and Consumer Service.

Hart, T GB. (2009) 'Exploring definitions of food insecurity and vulnerability. time to refocus assessments. Agrekon, 48(4), PP. 362-383.

Hawkes, C, and Ruel, MT.,(2011) 'Value Chains for Nutrition', paper presented at Conference Leveraging Agriculture for Improving Nutrition and Health, New Delhi, Food policy Research institute.

Hoddinott, J., (1999) 'Choosing outcome indicators of household food security: Citeseer, Washington D.C, International Food Policy Research Institute. 
Hussein, W., and Janekarnkij, P., (2013) 'Determinants of rural household food security in Jigjiga district of Ethiopia, Kasetsart J.(Soc. Sci), 34, pp. 171-180.

Jilani, A., Pearce, D., and Bailo, F. (2013). 'Wheat and maize projects in Afghanistan', Australian Centre for International Agricultural Research.

Jones, A., Ngure, F,. Pelto, G., and Young, S., (2013) 'What are we assessing when we measure food security?', A compendium and review of current metrics. Advances in nutrition, 4(5),pp. 481-505.

Kuwornu, J, KM., Mensah-B, A., and Ibrahim, H., (2011) 'Analysis of foodstuff price volatility in Ghana: Implications for food security', European Journal of Business and Management, 3(4), pp. 100-118.

Loopstra, R. and Tarasuk, V. (2013) 'What does increasing severity of food insecurity indicate for food insecure families? Relationships between severity of food insecurity and indicators of material hardship and constrained food purchasing', Journal of Hunger and Environmental Nutrition, 8(3), pp. 337349.

Maletta, H., Favre, R. J. K., FAO, and MAAH. (2003). Agriculture and food production in post-war Afghanistan.

Maxwell, S. (2001) 'The evolution of thinking about food security', Journal of Food security in sub-Saharan Africa,pp. 1331.

Mittal, S., and Sethi, D. (2011) 'Policy options to achieve food security in South Asia', Foundation Books New Delhi, India.

Mohamed, Ab A. (2017) 'Food security situation in Ethiopia- a review study',
International Journal of Health Economics and Policy, 2(3), pp. 86-96.

Mughal, M., and Fontan S, Ch., (2020) 'Cereal production, undernourishment, and food insecurity in South Asia' a Review of Development Economics, 24(2), pp. 524-545.

Muradi, A. J. and Boz, I, (2018) 'The contribution of agriculture sector in the economy of Afghanistan', Journal International Journal of Scientific Research Management 6(10).

Boz, Ismet NEPA. (2016) 'Afghanistan Climate Change Science Perspectives,NEPA', Rome, United Nations, Environment Programs (UNEP).

NRVA. (2008) 'National Risk and vulnerability Assessment 2011- 2012', KubulAfghanistan, Living Condition Survey.

NSIA. (2018) 'Islamic Republic of Afghanistan center Statistics Organization', Kubul Afghanistan, Afghanistan statistics Yearbook (2018-2019), pp. 111-123.

NSIA. (2020) 'Islamic Republic of Afghanistan center Statistics Organization', Kubul Afghanistan, Afghanistan statistics Yearbook(2019-2020), pp. 89-133.

Oxfam, M. (2007) 'Market Analysis Tools in Rapid - Onset - Emergencies Phase One Report', practical Action on Dunsmor Warwickshire, Philippines.

Oyakhilomen, O., Daniel, A Itodo.,and Zibah, R Grace., (2015) 'Technical efficiencyfood security nexus in Kaduna State, Nigeria: A case study of poultry egg farmers', Consilience, 2(14), PP. 244258.

Parvathamma, GL. (2015) 'An assessment on food security in developing economiesproblems and policy initiatives', IOSR J. Econ. Financ,2( 6), pp. 01-10. 
Poole, N., Amiri, H., Amiri, S. M., Farhank, I., and Zanello, G. (2019) 'Food production and consumption in Bamyan Province, Afghanistan: the challenges of sustainability and seasonality for dietary diversity', International Journal of Agricultural Sustainability, 17(6),pp. 413-430.

Poole, N., Echavez, Ch., and Rowland, D., (2018) Are Agriculture and nutrition policies and practice coherent? Stakeholder evidence from Afghanistan', Food Security, 10(6),pp. 1577-1601.

PROOF. (2017)' Household food security in canada, Canadian Institute of healthe Research, pp. 12-29.

Riely, Frank, Mock, Nancy, Cogill, Bruce, Bailey, Laura, and Kenefick, Eric. (1999) 'Food security indicators and framework for use in the monitoring and evaluation of food aid programs', Nutrition Technical Assistance Project (FANTA), Washington, DC.

Saidajan, A., (2012) 'Effects of war on biodiversity and sustainable agricultural development in Afghanistan', Journal of Developments in Sustainable Agriculture, 7(1), pp. 9-13.

Tavva, S., Aw-Hassan, A., Rizvi, J., and Saharawat, Y. S. J. O. o. A. (2017). Technical efficiency of wheat farmers and options for minimizing yield gaps in Afghanistan. 46(1), pp. 13-19.

Thomas, V., Ramzi, A. M. J. P., and Environment, W. (2011). SRI contributions to rice production dealing with water management constraints in northeastern Afghanistan. 9(1),pp. 101109.
UNDP. (2019) 'Inequalities in Human Development in the 21 st Century, Afghanistan , UNDP.

UNDP. (2003) 'Afghanistan Post-Conflict Environmental Assess- ment', United Nations Environmental Programme, Nairobi, Kenya.

UNICEF. (2012) 'Afghanistan Multiple Indicator Cluster Survey 2010-2011 Final Report', Kabul Central Statistics Organization (CSO) and UNICEF) (2).

UNICEF. (2014) 'National nutrition survey: Afghanistan (2013)', Kabul: United Nations Children's Fund. Retrieved from

USDA. (2007) 'Afghanistan Food Security Conditions and Causes -a special report by the Famine Early Warning Systems Network', Washington, Rome USAID.

USDA. (2013) 'The Relationship Between Food Insecurity, Conflict, and Food Price Shocks in Afghanistan', United States Department of Agriculture,Economic Research Service.

USDA. (2015) 'Food Security Country Framework for Ethiopia', Washington, Rome USAID

USDA. (2018) 'International Food Security Assessment from 2018-2028', Department of Agriculture, Economic Research Service, June 2018.

USDA. (2020) 'food Assistance fact sheet Afghanistan', America, Rome USAID.

Vozoris, N. T. and Tarasuk, V. S. (2003) 'Household food insufficiency is associated with poorer health', The Journal of nutrition, 133(1), pp. 120126.

Ward, F. A., Amer, S. A., and Ziaee, F. (2013) 'Water allocation rules in Afghanistan 
for improved food security. Food Security, 5(1), pp. 35-53.

WFP. (2009) 'Emergency Food Security Assessment Handbook, Second edition ed. World Food Programme', Food Security Analysis Service, Rome, Italy. World Bank. (2012) 'Poverty and Food Security in Afghanistan', Analysis based on the National Risk and Vulnerability, World Bank Home. .

World Bank. (2019) 'Food Insecurity in Afghanistan Five key policy-relevant findings about food insecurity', World Bank, home.

World Bank. (2014) 'Revitalization Agriculture for Economic Growth, job creation and food security, Rome World Bank.

World Bank. (2019) 'Food insecurity in Afghanistan, Five key policy-relevant findings of food insecurity', Washington, Rome World Bank.

World Bank. (2020) 'Afghanistan Development Update - Overview', Washington, DC , Rome Wold Bank. 